\title{
From Asia to the World: "Regional" Contributions to Global Migration Research
}

De l'Asie au Monde: contributions régionales à la recherche globale sur les migrations

Desde Asia al mundo: aportaciones regionales a la investigación global sobre las migraciones

Maruja M. B. Asis, Nicola Piper and Parvati Raghuram

\section{(Q) OpenEdition}

Journals

Electronic version

URL: https://journals.openedition.org/remi/12450

DOI: $10.4000 /$ remi. 12450

ISSN: $1777-5418$

\section{Publisher}

Université de Poitiers

\section{Printed version}

Date of publication: 1 October 2019

Number of pages: 13-37

ISBN: 979-10-90426-64-1

ISSN: 0765-0752

\section{Electronic reference}

Maruja M. B. Asis, Nicola Piper and Parvati Raghuram, "From Asia to the World: "Regional"

Contributions to Global Migration Research", Revue européenne des migrations internationales [Online], vol. $35-n^{\circ} 1$ et 2 | 2019, Online since 01 January 2021, connection on 15 April 2022. URL: http:// journals.openedition.org/remi/12450 ; DOI: https://doi.org/10.4000/remi.12450 


\title{
From Asia to the World: "Regional" Contributions to Global Migration Research
}

\author{
Maruja M. B. Asis', Nicola Piper² \\ and Parvati Raghuram ${ }^{3}$
}

Asia has become an empirical, theoretical and policy exemplar contributing to driving global migration research. Having experienced large-scale, sustained population movements since the 1970s, the continent has unsurprisingly become subject to rising scholarly interest. Empirically, cross-border SouthSouth or intra-regional migration in search of work and livelihoods has been a significant feature in Asia for many decades. Colonial mobilities included the transport of indentured labour both within and beyond Asia, and the long term movement of colonisers to the colonies and their return migration (Kaur, 2004). This has shaped postcolonial mobilities but these now exist amongst a panoply of migrant streams that are multi-directional. Many of these are intra-regional or inter-regional across countries of the global South as epitomised by the ChinaAfrica link (Mohan and Tan-Mullins, 2009; Pieke, 2012). For a long time migration was treated as a predominantly "single worker" phenomenon, with male migrants generally responding to the need for workers in the productive sectors. However, women have also migranted as workers, especially as domestic workers and to work in the manufacturing sector (Carter, 1995).

These empirical patterns have led to rich theorisations which are increasingly used globally. In particular, the concept of "care chain" (Hochschild, 2000; Parreñas, 2001), which has become widely used in global migration research and policy, draws on the experiences of migrant women from Asian countries who move abroad to meet the need for care workers in the global North, resulting in a care deficit in the migrant women's home countries. However, this concept already had a history in Asian thinking as an important precursor to the care

\footnotetext{
1 Executive Director, Scalabrini Migration Center, 40 Matapat St., Brgy. Pinyahan, Quezon City 1100, Philippines; marla@smc.org.ph

2 British Academy Global Professor, School of Law, Queen Mary University of London, Graduate Centre, Office No. 606, Mile End Road, London E1 4NS, UK; n.piper@qmul.ac.uk 3 Professor of Geography and Migration, The Open University, Milton Keynes, MK7 6AA, UK; parvati.raghuram@open.ac.uk

The authors would like to thank the three anonymous reviewers for their extremely useful comments and suggestions which have led to improved presentation and organisation of our thoughts and material.
} 
chain concept as popularised by Arlie Hochschild. It was Thanh-Dam Truong's (1996) important work on reproductive care which discussed such dynamics by drawing on the Asian case in the 1990s. She was among the early observers who noted the concentration of women migrant workers in Asia in "reproductive work" - both domestic work and entertainment - in contrast to men's work in productive sectors.

Finally, the mass recruitment of foreign workers on a strictly temporary basis constitutes a policy model which is spreading globally. It is increasingly treated as a solution to stagnating or failing "development projects" in countries of origin and, when considering the role fulfilled by precarious migrant labour in political economic terms, also in countries of destination. In the context of Asia, such policies have acquired dominant features in relation to private recruitment agency-mediated migration and the institutionalisation of migration governance. The role of the web of private recruitment agencies (acorss origin and destination countries) has been crucial in sustaining high levels of temporary labour migration in Asia - and constitutes therefore an important stakeholder (Battistella, 2014). One (intended or unintended) consequence of the labour migration of migrant workers on a temporary basis has been high levels of irregular migration and irregular employment practices. Another consequence is that many migrants are locked into a state of "permanent temporariness".

These empirical, conceptual and policy insights have been widely studied in Asian migration research but these contributions, the specificities of context and the variations that existing research within Asia point to are often ignored in wider migration research. This paper sets out to highlight these specific contributions of "Asian migration" to global migration research by presenting the context of migration from, to and and within Asia. It begins with a brief overview of Asian migration followed by a discussion of Asian migration research. The following section outlines some of the key contributions made by this research to global migration research and the implications of how this has been taken up selectively in subsequent research globally. The paper suggests that these global versions of Asian migration research are in need of further nuancing. Finally, the paper ends by highlighting how current Asian research also offers new avenues for theorising migration which are yet to be scoped.

The three foci identified in this paper are a tool for developing this line of argument. They are not meant to represent an exclusive list but are used to demonstrate dominant models of theorising and thus, the (often unrecognised) contributions made to global research whilst also highlighting the particular occlusions and exclusions that have resulted from those dominant models. The first theme is on labour migration; the second is family migration, and the third focus concerns governance and politics. 


\section{Asian Migration}

Asia has the largest number of international migrants of any continent around 80 million. Between 1990 and 2017 it increased by 31 million, the largest growth in the world (UN, 2017). 89\% of this growth could be attributed to intra-continental flows - most international migrants in Asia had been born in the region. 61 million of the world's migrants have moved within Asia, making it the largest intra-regional migration flow in the world. Between 1990 and 2000 only three of the top ten bilateral corridors were within Asia but between 2010 and 2017 that number had increased to six. The Gulf countries (classified as "West Asia" by the UN) is unique in terms of its extremely high percentage of non-citizen residents: Qatar and United Arab Emirates have the highest proportion of migrants to total population at 90 and $88 \%$ respectively, many drawn from within the continent and from Africa. There are, however, regional differences in the growth of migrant stocks; plus there are up to 7\% in Western Asia but almost zero in Central and Southern Asia.

According to ILO estimates of global migration stocks (2015), there were 150.3 million migrants workers in 2013 of whom 83.7 million are men, and 66.6 million are women. The proportion of women in Asian migration stocks is about $42.7 \%$ compared to $48.4 \%$ globally (UN, 2017). Much of this is due to sharp increases in the numbers and proportions of male migrants in Asia, which has outstripped the increases in migrant women. The Asia-Pacific region hosts $17.2 \%$ of this migrant workforce (25.8 million persons). Some of the Asian sub-regions have very high proportions of migrant workers in their worker population. For instance, $35.6 \%$ of all workers in the Arab States were migrants and $10 \%$ in Central and Western Asia. However, others such as Eastern Asia have very low proportions of migrant workers - only $0.6 \%$ - although this figure has to be treated with caution as it includes China which has a miniscule share of migrants in relation to its large population.

As elsewhere, some sectors of Asian labour markets such as construction, plantation/agriculture and fishing have a disproportionate presence of migrant workers, especially men. On the other hand, domestic work offers opportunities for many migrant women although in West Asia where domestic work also includes gardeners, drivers, security guards and cooks, male migrants tend to be employed in this sector too (Fernandez, 2014). 10\% of all domestic workers in the Arab region are men (ILO, 2015). In some countries, such as Korea, the manufacturing sector comprises mostly male migrant workers, while in Taiwan, electronics is dominated by women migrant workers. The garment sector also heavily employs female migrant workers from South Asia, as for instance in the Special Economic Zones in the Middle East (Tamkeen Center for Legal aid and Rights, 2011).

Temporary contract migration is recognized as mutually beneficial by governments and employers in destination and sending countries. In destination countries, temporariness facilitates labour market adjustment to economic fluctuations and to the socio-political sensitivities in multi-ethnic societies with on-going nation-building "projects". For origin countries, temporary labour migration facilitates regular and steady remittance inflows. Seven of the top ten remittance receivers in 2017 were Asian countries - India, China, the Philippines, Pakistan, Vietnam, Bangladesh and Indonesia (World Bank, 2017: 5). 
Moreover, Asia is also a source region of international migration of students. China and India are the largest student sending countries and account for a significant part of the international outflows of money paid for student fees, much of which flows outside the continent (Raghuram and Sondhi, 2017)4.

Finally, internal migration dwarfs international migration in Asia as elsewhere. Data as of around 2000 suggest a conservative estimate of 740 million internal migrants (UNDP, 2009 cited in Skeldon, 2017: 4). In populous Asian countries such as India, China and Indonesia, internal migration is a key driver of urbanisation and the rise of mega-cities.

In sum, Asia is increasingly important within the context of international migration, not only as a sending region but also increasingly for intra-continental flows. These flows have distinct gendered patterns and are concentrated in some sectors of the labour market, particularly domestic work.

\section{Researching Asian Migration}

In 2009, a survey of key regional academic journals and prominent migration research centres and networks noted that after a period dominated by economists and quantitative analyses, migration studies had begun to broaden out and become more inclusive in disciplinary and methodological terms (Asis et al., 2010). ${ }^{5}$ Resonating this, Huguet's review of articles published in the Asian and Pacific Migration Journal (2016) outlines the themes widely investigated in existing research: macro-level development, human rights of migrants, women in migration, social implications of migration, national policy making, multiculturalism and transnationalism. However, most existing research was found to be ahistorical and lacking a political economic lens. Moreover, gender analysis of migration, which relates to women and men's roles, paid little attention to masculinity, and was characterised by the absence of longitudional studies assessing social change and consequences of migrants over time, including an inter-generational perspective. Theoretically, it was found that ongoing critiques of modernisation theory had made little inroads into the literature on migration and hence, little space is given to post-development thinking and postcolonial epistemologies.

In subsequent years some of the themes identified have been expanded, others emerged, and still other topics have been dropped. These reflect, in part, new empirical realities given the shifts in the global economy and demographic trends in the intervening decade. The empirical foci have expanded in line with grounded shifts in migration in terms of directionality of migrations, altered role of sending and receiving countries, the profile of migrants, and questions generated by long-term stay and settlement as well as return migration.

4 See e.g. https://refugeesmigrants.un.org/sites/default/files/ts4_open_university.pdf. 5 This section builds on a review of Asian migration research conducted in 2008 which sought to examine the key knowledge frames on international migration in Asia in relation to the global debate on the migration-development nexus based on a broad view of what constitutes "development" (Asis et al., 2010). 


\section{Expanding Areas}

A topic that has received increasing attention is skilled migration. The drive to maintain their competitive edge and to transform their economies into knowledge economies has prompted Japan, Taiwan, Korea, Singapore, and fairly recently, China, to attract skilled migrants (UN, 2017). Among the highly skilled who add to China's roster are returning overseas Chinese or Chinese nationals. Some countries like China have become significant immigrant destinations for those both within and outside the continent. This is particularly evident in the case of student migration, with China emerging as one of the largest destinations for student migrants (Lan and Wu, 2016; Ho, 2017).

Similarly, and in line with the increasing multiscalar analyses of migration, cities have become an important meso-level analytical category (Findlay and Cranston, 2015; Shen, 2010). Transnational "creative knowledge migrants" (Florida, 2002 and 2007) are seen to benefit cities, especially those transititoning to post-oil economies, such as Dubai and Abu Dhabi, which are highly dependent on skilled migrants (and lesser skilled labour) (Ewers and Dicce, 2016) leading to new attention on the urban nature of migration.

The changing demography and nature of the family in Asia are also receiving increasing attention. Rapidly ageing societies, especially in East Asia, have resulted in more consideration being paid to issues such as the demand for care workers to assist the elderly (Ogawa et al., 2017; Yeoh and Huang, 2012). While migrants care for older residents, their own ageing and care has been relatively neglected. This is an area for research and policy in the future. Similarly, the impact of migration on shifting family-based care arrangements, including the role of fathers and grandparents as carers, has also grown (Hoang et al., 2011; Knodel and Ngyuen, 2015).

At the other end of the age spectrum, migrant children have also become an object of attention (Beazley, 2015; Beazley et al., 2017; Waters, 2017). In the Asian context, given the reality of strictly temporary contract migration, most research has focused on children left behind, those born to migrants (Kim et al., 2017) and those who are reunited with their mothers returning after divorce or separation (Graham and Yeoh, 2013; Asis, 2006; ECMI, AOS-Manila, SMC and OWWA, 2004). The socio-legal precariousness of their situation has been a key investigative lens. Others have focused on the 1.5 and second generation children, some of whom are the offsprings of mixed couples and thus the product of "marriage migration" (Nagasaka and Fresnoza-Flot, 2015; Asis and Liao, 2017). However, Asian research on migration and children also point to the aspirational nature of the Asian family. In "astronaut families", typically mothers in middle and upper class families from Hong Kong, Japan, Taiwan and Korea have moved to the global North to facilitate access to what they perceives as world class education and sometimes to citizenship (Tsong and Liu, 2009). Singapore too is becoming a destination for Chinese students who are accompanied by their "study mothers" (Huang and Yeoh, 2011). Another variant is sending children abroad for pre-tertiary education, the so-called "early study abroad", to enhance the children's chances of getting into prestigious universities (Kim, 2013; Shin, 2013; Kwak, 2013). These phenomena stand in stark contrast to the literature on Africa, for instance, where child migration is seen to epitomize poverty and AIDS (van Blerk and Ansell, 2006). 


\section{Emergent Topics}

An emergent area of research has arisen due to the shifting nature of the region in the global political economic imaginary. Captured by notions such as "Rising Asia" this has led to distinctively new research concerns.

One reason for this is that the global economic recession (2007-2013) had no significant or lasting effect on migration patterns. Unlike the 1997 crisis that hit much of South and South East Asia, the region was relatively unaffected by the downturn, and thus, migration continued (Park et al., n.d.). In India the Ministry of Home Affairs (2010) reported that there are almost 400,000 foreigners of whom students (25\%) and employees (11.5\%) make up an important part (p. 158). However, there is also a large complement of cross-border migrants particularly from Bangladesh. For instance, the World Bank (2008) estimated that in 2005 there were 5.7 million immigrants in India of whom $2.8 \%$ were categorised as refugees. Either way it is clear that India like China are at least regional migration poles. This is a new area of research that has developed in the last decade and has the potential to unsettle the place attachments (south as sending, north as receiving) inherent in much of the migration and development literature (Raghuram, forthcoming).

It is not only new migrants who are turning to Asian destinations, there are a number of return migrants too (Chacko, 2007; Wadhwa et al., 2009; Piper and Withers, 2018; Paul, 2017; Battistella, 2018 and 2014). A number of people are returning because of the enhanced entrepreneurial opportunities they see there (ILO, 2010; Giordano and Terranova, 2012; Jain, 2013; Pieke, 2012; Willis and Yeoh, 2000). However, not everyone's return is voluntary or celebratory. For many migrants return is due to the foreclosing of opportunities because of the contraction of economic opportunities following the economic crisis not only from Gulf countries (Prakash, 2013; Buckley, 2012) but also from the US. Return was a necessity, not an option (Spitzer and Piper, 2014).

In Asia, return is, in fact, not necessarily the end of temporary migration as migrants may not return to their home countries after working in an overseas destination, but may migrate onwards to other destinations in stepwise migration (Paul, 2017) Other onward destinations like the UK are increasingly restricting opportunities for migrants (Cavanagh, 2012) so the double action of economic crisis and anti-immigrant sentiment in the West with rising opportunities in the Rising Powers may lead to new horizons of mobility as well as immobility (ILO, 2010; Jain, 2013; Wiesbrock, 2008).

While the growth of regional flows has generated attention, this has also occurred at a time of growth of multilateralism, another area of increasing research attention. For instance, multilateral processes and the emergence of the discourse on "migration management" as well as the revival of the migration-development nexus debate have influenced the way in which migration has been researched in Asia (Huguet, 2016).

\section{Declining Topics}

Although there is greater focus on sexuality (Smith, 2010; Lyttleton, 2014), research on sex workers has declined. For instance, entertainer migration has 
been much less under the research radar, largely because the legal migration of entertainers to Japan, the primary destination, has been reduced since 2005. Censured by the US Anti-Trafficking Reports, Japan introduced stricter requirements in the admission of entertainers, which drastically cut the number of entertainers, primarily from the Philippines. Korea continues to receive entertainers, but the numbers are small compared to Japan. All this has meant that this particular research focus has shrunk in recent years.

In line with the expansion of the field, we can observe shifting paradigms on the migration literature on Asia. Moreover, research that used to be predominantly published in local languages is now beginning to appear in English, especially studies carried out by East Asian scholars ${ }^{6}$, so that horizons of visibility and attention amongst researchers is also changing.

\section{Lodestars of Asian Research}

In this section we briefly outline three main foci - labour migration, families and politics - in Asian migration research, the metanarratives they have produced and how these metanarratives are being challenged. We use the term lodestar for these foci as they have become Asian exemplars that have guided so much global research subsequently. We do so in order to expand the imaginaries of Asian migration and to suggest new avenues of research.

\section{Labour Migration}

One of the key contributions of Asian research to global migration literature is the concept of care chains (Parreñas, 2012). Drawing on the empirical example of Filipina migrants in the US, Arlie Hochschild coined the term "care chains' to look at the ways in which caring labour is transferred up the chain from urban Philippines to the US and is replaced by migrant workers from rural or semiurban areas. This metaphor of chains was used to look not only at the redistribution of migrant caring labour but also of affect, with implications for children becoming a particular concern.

The concept of care chains attempts to capture a whole series of movements as well as their differential but interlinked causalities. This work led to a plethora of new research across the world where similar patterns were observed. As a result, the concept of care chains came to be widely adopted. However, its popularity has meant that the analysis of mobility of women has become particularly skewed. First, th meaning and arrangements of care vary and so Asian case should not be used without local specification. For instance, variations in the care diamond, i.e. the institutional factors that shape care - the state, market, household and community - as well as in the definitions of care are often lost (Raghuram, 2012). The role of the state in care provision varies both in financing and direct provision of care. The family too is variable in how care is articulated along gender and generational lines (see below). Besides, the government often

6 The main reason for this is a new cohort of scholars who are conversant in the English language, having done their PhDs in countries where English is the dominant medium, followed by post-doctoral fellowships. There are still many scholars in East Asia though who primarily or exclusively publish in their local language. 
has a large say in the extent and nature of private provision of care, either as an agent of the state, or as individual provider. Many of these providers may themselves be transnational and the extent to which these other nodes are transnational will therefore vary.

Secondly, research on care chains has differential foci depending on which end of the chain is being studied. In the global South sending context, patriarchy and the family and the effects on children receive considerable attention but in the global North it is the withdrawal of the State and the neoliberalisation of care which receives attention. Yet, this ignores the excellent work that was done on the unequal gender divisions of caring labour in the North in the 1970s and 1980s, especially in the precursor of the care debate - the domestic labour debate (see for instance, Hartmann, 1981) Then, it was precisely these gender inequalities in caring that received attention. Thus, Orozco (2009: 10) argues that although "care chains are led by women, we must consider the places that other actors, especially men, public institutions and businesses occupy, in order to identify the absence of these actors in terms of accountability and in terms of receiving the benefits of care that results from the chains." Else we are in danger of repeating, yet again, an obsession with the resultant figure of the subaltern woman - the object of many academics' fantasies and anxieties as many postcolonial authors have convincingly pointed out (Mohanty, 1993; Puwar, 2003). Besides, care chains research has also been critiqued for its' methodological sexism: women are only seen as caregivers, while all care-giving is seen as female overwritten by a normativity whereby women's failure to give care is negatively viewed (Dumitru, 2014). Moreover, migration can unsettle established notions of gendered behaviour.

Besides, the global South is largeley seen as a site and source of unskilled labour. Given the importance of these flows this is not surprising. However, migration flows are more complex and intersecting and include skilled workers. Thus, Willis and Yeoh (2000) and Muir et al., (2014), for instance, draw on the experiences of women migrants to China. Comparing these tells us about the differences between those who move through company assignments and those whose move is self-initiated. Although there is no systematic overview of numbers involved, the latter group seems to have more women. They often move in order to overcome gender and other barriers in their existing countries or as spouses (Muir et al., 2014). The latter also move laterally, while the former are often deskilled, employed for their cultural knowledge rather than their particular skills, and may be incorporated temporarily to fill some roles. They, in effect, find it much harder to benefit from movement.

Yet class enables such workers to escape precarity, a theoretical framework increasingly used for theorising female migration globally (Goldring and Landolt, 2013, Lewis et al., 2014). It has been applied to destination countries but much less is known about precarity as a factor leading to out-migration in the first place. Until recently, the language of precarity has been conspicuously absent from much of the literature on the Global South (Piper et al., 2017). This is surprising because migration cannot be seen as a linear path into precarity or a means by which migrants become precarious. Rather, foreign employment should be understood as precarious work undertaken to mitigate existing conditions of precarity at home (Sassen, 2002). In the specific context of strictly 
temporary migration leading invariably to return migration and often to re-migration, precarity emerges as "protracted"This is especially the case in Asia with its extended web of private recruitment agencies leading to migrants incurring debts due to the burden of having to finance their own travel arrangements and job placement. What emerges from this is a view of precarity as a transnational experience that is spatially reconfigured through migration but, nonetheless, represents a constant experience for migrant workers torn between social relations with their natal families and communities and those established in the country of destination.

The concept of precarity, especially its "protracted" nature (Piper et al., 2017), also allows us to move beyond classic development concerns of poverty alleviation, as international migrants are not necessarily the poorest of the poor or characterised by low levels of education. Nor are their reasons for migrating necessarily or even predominantly economic. Like male migration, female migration is motivated by a complex web of social relations. In this sense, precarity takes on multifaceted meanings in cultural, social, and economic terms and is reflective of a multi-layered state of crisis (care, decent work, individual freedoms versus collective needs).

As Spitzer and Piper (2014) argue, the context of labour migration in Asia reflects a precarity brought on by a multiplicity of long-standing social, economic, and political concerns that workers have faced at home and abroad (also see Belanger and Tran Giang, 2013). In the Philippines, for example, decades of neoliberal measures derived from structural adjustment policies have led to continuing employment instability, compelling workers to shift in and out of informal sector employment locally and into contract employment overseas. The rising demand in the global economy for health and domestic workers is the main driver of female migration from the Philippines, Indonesia and Sri Lanka. Other countries later followed suit, but not without much ambivalence. The precarity of Asian migrant workers in the current economy is not a new situation but an ongoing one, rooted in the exigencies of neoliberal globalization and globally networked capitalism.

\section{Changing Migration, Changing Families}

International labour migration is traditionally seen as a mechanism responding to economic and demographic differentials between resource-poor origin countries with labour surplus and more developed destination countries with labour shortage. The family or household was inconsequential in theoretical considerations of migration until the introduction of the new economics of labour migration or NELM (Stark and Bloom, 1985). In this meso level framework, migration is posited as a household strategy for survival or mobility, and locates migration decision-making as a household function instead of deriving from individual action or acted upon by structural forces. While NELM contributed towards understanding the whys or determinants of migration, particularly in the global South, where social protection is inadequate and individuals often have to rely on family-based resources, it is silent on the consequences of migration for families and households in origin countries. 
In Asia, international labour migration has implicated families and households in divergent and myriad ways, particularly those in origin countries. The strictly temporary labour migration regime in the region created transnational families with migrant workers overseas and their families "left behind" in the origin countries. The separation of migrants and their families invites questions on the gendered renegotiations of power when men migrate and women are left behind (Asis, 2006). Studies on the impact of male migration on "left-behind" families suggest the continuation of male roles as the family breadwinners (Asis and Marave, 2013). In their absence, "left-behind" wives assume dual roles as mothers and fathers to their children, experiences which produced a doubleedged consequence: it increased their responsibilities on the one hand, but it also led to new learnings on the other hand, increasing involvement in money transactions and power over decision-making (Gulati, 1993).

Concerns over the effects of migration on families magnified when female labour migration started in the 1980s, finding an audience particularly in the court of public opinion (ECMI, AOS-Manila, SMC and OWWA, 2004; IOM and SMC, 2013). Public anxieties and policy concerns of the family impacts of temporary labour migration invited much academic and research interest in origin countries in the region. Most concerns center on the impact of parental absence on the "left-behind" children. The departure of mothers is considered more problematic for the children because of the role of mothers as primary carers. For migrant women, women's migration holds the possibility of transforming gender roles within the family. With their greater earnings, women migrants become the main breadwinner in their roles, thereby transgressing traditional gender division. Unlike male migration, women's migration may be driven by non-economic factors, such as gender surveillance, domestic violence, or escape from a problematic marriage, especially in contexts where women may be stigmatized when their marriage fails (Kim et al., 2017; Constable, 2003). Unlike the work of male migrants in the productive sector, women migrants' work in the reproductive sector presents daily reminders of the care work they relinquished in their families which they provide to the families that employ them.

The specific case of intra-regional migration Asia requires us to review the notion of the family in general. In Asia, migration is a family project undertaken to advance the welfare of the family and is supported by family members. Grandparents are among non-parental carers on either migrants' maternal or paternal family who step into the carer's role. In Indonesia and Philippines, migrants tend to rely more on maternal side while in Vietnam, the paternal family plays a larger role in providing care to left-behind children (Hoang et al., 2015). The extended family, and the intergenerational contract between parents and children suggest the availability of family and kin to step in when parents migrate (Knodel and Nguyen, 2015), does not have the same ring of loss as in some Western nuclear family households.

Research in Asia on how international migration affects young children has been quite extensive. The Child Health and Migrant Parents in Southeast Asia (CHAMPSEA) study is particularly informative because it is based on survey data with fairly large samples which provides a gendered, comparative and longitudinal analysis of how parental absence due to international labour migration affects the health and well-being of young children. Data for the first wave, 2008 
and 2009, were collected in Indonesia, the Philippines, Thailand and Vietnam; the second wave was conducted in the Philippines and Indonesia in 2016 and 2017.

Overall, they found that remittances have improved the material conditions of transnational families (Graham and Yeoh, 2013: 310). Contrary to popular views, the health and well-being of the "left-behind" children are not compromised by parental absence. In terms of psychological well-being (based on caregiver reports from the Strengths and Difficulties questionnaire - SDQ), children in father-migrant households in Indonesia and Thailand are more likely to have poor psychological well-being, compared to children in nonmigrant households, while this was not the case in the Philippines and Vietnam (Graham and Jordan, 2011). Other studies probing the impact of parental migration on a range of psychological well-being, such as resilience in Thailand (Jampaklay and Vapatannawong, 2013), and physical health indicators, such as child stunting in the Philippines and Vietnam (Graham and Jordan, 2013), alcohol use in Vietnam (Jordan et al., 2013), smoking in Indonesia (Sukamdi and Wattie, 2013), and school performance in the Philippines (Asis and Marave, 2013) showed variations between countries or children in transnational families faring just as well or better than children co-residing with both parents. Children in transnational families are doing well mostly because the care of children continues to be carried out by family members. Instead of a care deficit, CHAMPSEA noted a care triangle in place among transnational families involving the migrant parent(s), the non-migrant carers at home (which may include the "left-behind" parent or another family member, such as grandparents) and the child (Graham et al., 2012). Family relationships were maintained due to real-time communications between migrants and their families at home. While developments in information and communications technology allow for connectivity, they have also reconfigured being family in the context of transnational migration (Acedera, Yeoh and Asis, 2018).

Fathers were identified as the principal carer of young children by $71 \%$ of households in Vietnam, $68 \%$ in Indonesia, and $60 \%$ in the Philippines among mother-migrant households (Lan et al., 2015: 268). The survey findings supplement earlier qualitative studies (Pingol, 2001 and Asis et al., 2004 in the Philippines, and Gamburd, 2000 in Sri Lanka) which found fathers taking care of their children while their wives work abroad. These provide a counter-narrative to negative public opinions about irresponsible husbands and uncared children while their wives and mothers labour abroad, including findings on delinquent husbands (Parreñas, 2005). ${ }^{7}$ Few father-carers are full-time carers; most of them continued working outside the home, which, for many, involved balancing their provider and carer roles (Asis, Mendoza and Marave, 2016; Hoang and Yeoh, 2011). From their analysis of migrant wives and left-behind husbands in Vietnam, Hoang and Yeoh, 2011) offered important take-away insights: that men do not fall apart or resort to hyper-masculinity because their migrant wives have more

7 In Sri Lanka, findings from a study that found left-behind children not cared for by fathers led to a policy that prevented women with children under five years old from leaving to work overseas (Save the Children Sri Lanka, 2006; Perrera and Rathnayaka, 2013). In the Philippines, the social costs of migration are viewed by policymakers and advocates largely in terms of perceived ill effects on families, i.e., migration as contributing to marital dissolution, alienation between migrant parents and their children, and a host of juvenile delinquency problems (Asis and Roma, 2010). 
economic power, and instead of the simplistic dichotomy of separate masculine and feminine spheres, the findings point to the complexity and flexibility of lived (rather than expected) gender relations and identities.

International migration in Asia, thus, casts light on the family as a stakeholder situated between the global and the local, between the market and the state, and as an important safety net for families in origin and destination countries. The research interest spurred by migration "has opened up the Asian family as a material and ideological construct to academic scrutiny, and in the process paved the way for a more critical understanding of gender identities and relations" (Yeoh, 2014: 142).

\section{Governing Migration: Politics and Policy}

Labour migration has over the last decades also led to greater and more intensified institutionalisation on national, regional and global level - with some coordination among those - which in turn has contributed to sustained flows of temporary migrants. The gradual institutionalisation has been underpinned by particular discourses on migration, linking it to development (the preference by states) and human rights concerns (preference by civil society).

The structural permanence and expanding volume of temporary contract migration, its gendered form and implications for families in Asia have initiated studies taking a more critical view of the migration-development nexus debate highlighting the monetary and social "costs of migration". This has been paralleled, if not triggered, by rising politicisation of this type of migration and by an expanding migrant rights activism in Asia. Where such activism has taken on the form of transnational advocacy networks, with the aim of shaping global debates on migration regulation, the objective - and outcome - has been to develop a counter-discourse to the state-led "migration management" frame with its focus on population control rather than a human-centred rights-based approach (Piper and Rother, 2012 and 2014; Piper, 2010). The concept of "governance" has served as a bridge between debates on policy and politics.

The "Asian" way of "doing" migration policy has been based on a narrowly defined regulatory framework whose strictly temporary nature is being navigated (and circumvented) creatively by a range of non-state actors "on the ground" in a variety of ways (Franck et al., 2018). These dynamics between "top down" and "bottom up" processes has given rise to contributions to global governance studies which introduce a perspective emanating from various migrant and civil society initiatives and networks and/or the involvement of a web of facilitators, that is recruiters and brokers (Baas, 2018), to what has otherwise been treated as a state-led arena.

Most research on migration policy has been conducted in a national context taking individual or pairs of countries as point of reference (see also Huguet, 2018). There is still a dearth of research on regional governance or global governance in relation to regions in relation to the role of international organisations in Asia (for exceptions see Kneebone, 2010; Grugel and Piper, 2007). Such lack of research is partly explained by the fact that compared to other regions, an "Asia" formal institutional architecture at regional level (e.g. ASEAN) is poorly developed (Lavenex and Piper, forthcoming). However, apart from formal 
processes there are informal ways of governing that are worth examining, such as the so-called regional consultative processes. Other newer developments concern ASEAN's efforts at harmonising and recognising of skills and qualifications (Jurje and Lavenex, 2018) and enhancement of student mobility (Welch, 2018). Such topics deserve more systematic study.

The Asian experience has led to a fledgling literature taking a critical stance on the 'development' impact of temporary contract migration (Chi, 2007; Gibson et al., 2008; Hugo, 2009; Piper and Lee, 2017; Piper, Rosewarne, Withers, 2017) and the costs of migration (Baas, 2018). Such analyses have typically involved a transnational lens and led to the recent call for balancing the more celebratory tenor of "transnationalism studies" which is typically derived from the experience of South-North migration (Piper and Withers, 2018).

The rise in studies on transnationalism by migration scholars from around the world has resonated with scholars of Asian migration since it calls into question the underlying premises of "permanent" migration. Having originally started by anthropologists working on the case of Central Americans in the US ${ }^{8}$, research on transnational migration which is informed by, or emanates from, the experience of Asian migrants and the dynamics of intra-Asian migration have been increasingly subject to this line of inquiry also. The insights from human geographers and cultural sociologists working on "Asian" transnationalism, however, tended to add to this expanding body of scholarship without making conceptual advancement based on a more critical engagement of the specific reality of migration in Asia which does entail rupture - not because of settlement, however, but due to "forced" return (Piper and Withers, 2018). Such critiques are typically the product of political economists and political sociologists whose work has built bridges to regulation or governance studies by highlighting institutional aspects such as the role of cross-border networks in relation to multilateral and bilateral policy processes.

The role of institutional actors at multiple levels (that is, local, national, regional and global) in the shaping of migration policy and the facilitation of migratory movements has been a phenomenon scholars working on intra-Asian migration have for long grappled with. Studies on migrant networks (Thieme, 2006; Nguyen, 2018) and collective organising by them or on their behalf (Piper and Rother, 2012 and 2014) are a reflection of the increasing number and diversity of institutional actors, located not only within the state but also at sub-state and supra-state levels, involved in shaping or regulating the flow of migrants. Studies on global migration governance have shown that the issues engaging policy makers and advocates go well beyond controlling people's exit from one country and entry into another and are increasingly perceived as requiring not only bilateral but also multilateral cooperation (Koser, 2010; Betts, 2011). The lack of pathways to permanent residence, let alone citizenship,for the majority of the low skilled, low-wage migrants is indicative of the highly restrictive regulatory environment which does not offer access to many rights. Studies have shown

8 Roger Rose was one of the first anthropologists to challenge the bipolar mode of migration that was popular in the 1970s and 1980s and thus the division of migrants into two types: sojourners and settlers. Through his concept of "transnational migrant circuits" he exposed the problematic nature of the abrupt rupture of ties between sending and receiving communities that dominated thinking (Rose, 1995). 
that the lack of clear policies dealing with rising phenomena of international marriage (Piper and Roces, 2003) has resulted in lacking programs for migrant integration or incorporation, legal and institutional voids in relation to transnational divorce (Quah, 2015) and return migration of non-citizen mothers and children (Kim, 2017). In the context of legal precarity, the issue of statelessness is also pronounced in Asia (Allerton, 2014). By and large, Asian countries are continuing to assert their sovereignty over territorial borders and population movement (Piper et al., 2018), whilst the emergence of migration governance in a regional and global context as an institutional process running parallel is at an all-time high (Piper and Ramia, 2018). This comes with the realisation of the fact that state responsibility is complicated by rising cross-border mobility and the phenomena of 'absentee citizens' and non-citizen residents.

In the sphere of migration, the upholding of rights is rendered difficult by the fact that migrants cross national borders and as "non-citizens" or "absentee citizens" their rights are harder to implement by institutions and regulatory frameworks which are still overwhelmingly nationally oriented. This is further compounded by the prevailing temporary contract migration, leading to definitive return migration at the end of a two to four year contract or the slipping into an undocumented status upon overstaying, with marriage migration one of the rare exceptions of offering a pathway to permanent residence (yet rarely citizenship). Yet, as recent studies on the latter have shown, Asian governments are still grappling with filling legal and institutional gaps to address the rising incidences of international divorce leading e.g. to mixed children's statelessness and other problem issues (Kim et al., 2017).

In addition to citizenship, another arena of protection constitutes international human rights law, since the rights of migrants (even more so when strictly temporary) fall into the responsibility of at least two states - origin country and destination country. But real or perceived failures of international law on migrants have been amply demonstrated (Darrow and Arbour, 2009), and some scholars (such as Neil and Peterie, 2018) have highlighted strategies which governments use to flout their international obligations (Piper and Iredale, 2003). Human rights have, therefore, been described as having a precarious status within international institutions in general (Charlesworth, 2017) and in relation to regional institutions. The regional institutional level can form a bridge between the global and the national/local and thus constitutes another vital step in the gradual acceptance of human rights as truly universal norms. This does not come without its own challenges in light of the different political systems offering more or less limited space for civil society participation.

Migrant rights issues have been subject to fairly extensive research from the viewpoint of civil society activism in Asia (Yeoh et al., 2008; Nah, 2014 ). The findings show that generally speaking migrants' voices are now better represented due to the fact that migrants have set up their own organisations (often upon return) (Ogaya, 2003) and also engage in advocacy networks at local, national, regional and global level. The rise in collective organising and the formation of transnational and inter-regional networks is in response to but also creates, political opportunities for gaining some form of improvement in migrants' socio-legal circumstances (Piper and Rother, 2014). The ways in which thes different levels (regional-national-local) of governance are interlinked and 
the role and influence of governmental and non-governmental actors deserve more detailed research.

\section{Conclusion: New Research Agendas}

We are seeing shifts in global political arrangements which have stood for the last twenty-five years, and migration has been central to some of these shifts. Both Brexit and US politics have drawn on the extant immigrant sentiment which seems to be engulfing parts of the world. It is therefore also reshaping migration. Current policies of forced return, and of blocking entry, even of skilled migrants along with the dissolution or threats to dissolution of free movement has meant that labour and families will be differently put together in the next decades. In doing so, Asia, with its large population and some thriving economies is becoming one of the new centres in a multipolar global arrangement (Pieterse, 2013). Asian migration is thus worth watching.

Our review of the empirical theoretical and policy implications of the previous section shows that there has been a large focus on reproductive sectors of the labour market, yet the articulations between production and reproduction need further work. For instance, how are the lives of migrant and non-migrant men and women in productive sectors, such as finance but also in manufacturing being made possible through the reproductive labour of families? Moreover, as migration for education climbs sharply up the agenda in Asia, how is this paid for? What kinds of work have been required in order to enable migration for education?

The Asian family has become the exemplar of appropriate femininities, something which has been raised by research on the socially reproductive sectors worldwide. Domestic workers and nurses globally have depended on the care meted out by such appropriate femininity. However, as the paper has shown these femininities are not universal across Asia. They are also altering within the context of a rising Asia. And they have particular implications for feminist activities and transnational solidarities.

Theoretically, most migration and development literature looks at mobility not as a way of allowing countries (as imagined 'nation-states') to reach out and influence, but as an incursion of borders. Yet, in a globalising world mobility is a central modality through which economic and political power is exercised. This is clearly evident in the case of China. Both capital growth and political influence are acquired through the movement of people. These mobilities have been facilitated to extend the country's reach. This suggests the need for analysis of how power as a relational concept is and has been practised through migration. The literature that focuses on the effects of migration on development sees migration and development as cause and effect, not as a necessary relation. However, migration is a way of governing societies, not just an object of governance by society (Bærenholdt, 2013).

The focus on the relationship between different forms of mobility is also a topic which needs more attention. What role does the movement of people play in the flow of goods, ideas, policies and money? When is migration a necessary party of investments abroad and what are the different kinds of mobility that 
these require? Thus, what role does the mobility of people play in the rise to power? This question may be asked historically of "older powers" as well as of those which are currently seen to be emerging. Asking these questions effectively decentres the migrant as the object of study; instead power, its modalities and the part played by mobility in power and influence of the nations to which migrants move too becomes part of the focus.

Despite its focus on Asia, the paper clearly suggests that although there are indeed Asian particularities, there are also generalities. Black theorists, feminists and postcolonial theorists have suggested the need to rethink the existing divisions of the world between Global North and Global South or between continents as in area studies, but instead to examine vectors of power. They argue that the optic of gender, race and class complicates the three-fold division by suggesting new kinds of alliances and different types of disagreements. Fraser (2010) calls the third world that emerges from this kind of analysis the 'transnational precariat'. The precariat exist simultaneously in different parts of the world but are caught up in the intersectional power relationships that increasingly stretch transnationally. They stretch between sending and receiving countries requiring sensitivity to transnational rights.

In sum, the rise in intra-Asian migration is characterised by multi-directionality and the result of multiple purposes and circumstances. From a global perspective, we would argue that Asian specificities lead to important generalisations for the study of migration more broadly, by way of a move to a multi-centred, multi-nodal model of international migration; and the formation of transnational class and migrant precariat as a transnational process and phenomenon. Both trends and frames have implications for future research and theorisation. This paper has taken some tentative steps towards such a paradigm shift.

\section{References}

Allerton Catherine (2014) Statelessness and the lives of the children of migrants in Sabah, East Malaysia, Tilburg Law Review, 19 (1-2), pp. 26-34.

Asis Maruja M. B. (2006) Living with migration: Experiences of left-behind children in the Philippines, Asian Population Studies, 2 (1), pp. 45-67.

Asis Maruja M. B., Huang Shirlena and Yeoh Brenda S. A. (2004) When the Light of the Home is Abroad: Unskilled Female Migration and the Filipino Family, Singapore Journal of Tropical Geography, 25 (2), pp. 198-215.

Asis Maruja M. B. and Liao Karen Anne S. (Eds) (2017) Moving Portraits: Life Stories of Children of Migrant and Multicultural Families in Asia, Quezon City, Scalabrini Migration Center, $145 \mathrm{p}$.

Asis Maruja M. B., Mendoza Valentin and Ruiz-Marave Cecilia (2016) No Longer Just a Mother's Job: Filipino Fathers as Carers in Transnational Families, in Benny Hari Juliawan Ed., Left-Behind Children and the Idea of the Family, Yogyakarta, Penerbit PT Kanisius, pp. 1-16.

Asis Maruja M. B., Piper Nicola and Raghuram Parvati (2010) Migration and development in Asia: knowledge frameworks, International Migration, 48 (3), pp. 76-106. 
Asis Maruja M. B. and Roma Golda Myra (2010) Eyes on the Prize: Towards a Migration and Development Agenda in the Philippines, in Fabio Baggio Ed., Brick by Brick: Building Cooperation between the Philippines and Migrants' Organizations in Italy and Spain, Quezon City, Scalabrini Migration Center, pp. 35-138.

Asis Maruja M. B. and Ruiz-Marave Cecilia (2013) Leaving a Legacy: Parental Migration and School Outcomes among Young Children in the Philippines, Asian and Pacific Migration Journal, 22 (3), pp. 349-376.

Baas Michiel (2018) What Determines the Cost of Migration? A Perspective from Indian Agents Facilitating Migration to Singapore and the Middle East, Working Paper Series no. 264, Asia Research Institute, National University of Singapore.

Bærenholdt Jorgen Ole (2013) Overnmobility: The politics of mobility, Mobilities, 8 (1), pp. 20-34.

Bakewell Oliver and Jónsson Gunvor (2011) Migration, mobility and the African city, Working Paper 50, Oxford, IMI.

Battistella Graziano (2018) Return Migration: A Conceptual and Policy Framework, [online]. URL: http://cmsny.org/publications/2018smsc-smc-return-migration/

Battistella Graziano (2014) Migration in Asia: In Search of aTheoretical Framework, Graziano Battistella, et al., Global and Asian Perspectives in Migration, Springer, pp. 1-24.

Battistella Graziano and Ma Cecilia G. Conaco (1998) The impact of labour migration on the children left-behind: A study of the elementary school children in the Philippines, Sojourn, 13 (2), pp. 220-241.

Beazley Harriot (2015) Multiple Identities, Multiple Realities: Children Who Migrate Independently for Work in Southeast Asia, Children's Geographies, 13 (3), pp. 296-309.

Beazley Harriot, Butt Leslie and Ball Jessica (2017) "Like it, don't like it, you have to like it": children's emotional responses to the absence of transnational migrant parents in Lombok, Indonesia, Children's Geographies, [online]. URL: https://doi.org/10.1080/14733285.2017.1407405

Belanger Daniele and Tran Giang Linh (2013) Precarity, Gender and Work: Vietnamese Migrant Workers in Asia, Diversities, 15 (1), pp. 1-4, [online]. URL: www.unesco.org/shs/diversities/vol15/issue1/art2

Betts Alexander (2011) Global Migration Governance, Oxford, University of Oxford Press.

Carter Marina (1995) Servants, Sirdars and Settlers: Indians in Mauritius, Delhi, Oxford University Press.

Charlesworth Hilary (2017) A regulatory perspective on the international human rights system, in P. Drahos Ed., Regulatory Theory, Canberra, ANU Press, pp. 357-374.

Chi Xinying (2008) Challenging Managed Temporary Labour Migration as a Model for Rights and Development for Labor-Sending Countries, NY University Journal of International Law and Politics, 40, pp. 497-540.

Constable Nicole (2003) A Transnational Perspective on Divorce and Marriage: Filipina Wives and Workers, Identities, 10 (2), pp. 163-180. 
Darrow Mac and Arbour Louise (2009) The pillar of glass: human rights in the development operations of the United Nations, American Journal of International Law, 103, pp. 446-501.

Dumitru Speranta (2014) From "brain drain" to "care drain": Women's labor migration and methodological sexism, Women's Studies International Forum, 47 (B), pp. 203-212.

Episcopal Commission for the Pastoral Care of Migrants and Itinerant People/ Apostleship of the Sea-Manila, Scalabrini Migration Center and Overseas Workers Welfare Administration (2004) Hearts Apart: Migration in the Eyes of Filipino Children.

Ewers Michael C. and Ryan Dicce (2016) Expatriate Labour Markets in Rapidly Globalising Cities: Reproducing the Migrant Division of Labour in Abu Dhabi and Dubai, Journal of Ethnic and Migration Studies, 42 (15), pp. 2448-2467.

Fernandez Bima (2014) Essential yet Invisible: Migrant Domestic Workers from the GCC. Gulf Labour Markets and Migration, GLMM-EN, 4/2014, [online]. URL: http:// cadmus.eui.eu/bitstream/handle/1814/32148/GLMM\%20ExpNote_04-2014.pdf

Fraser Nancy (2010) Injustice at Intersecting Scales: On "Social Exclusion" and the "Global Poor", European Journal of Social Theory, 13 (3), pp. 363-371.

Gamburd Michelle (2000) The Kitchen's Spoon Handle: Transnationalism and Sri Lanka's Migrant Housemaids, Ithaca and London, Cornell University Press.

Goldring Luin and Landolt Patricia (2013) Producing and Negotiating Non-Citizenship: Precarious Legal Status in Canada, Toronto, University of Toronto Press.

Graham Elspeth and Lucy P. Jordan (2013) Does Having a Migrant Parent Reduce the isk of Undernutrition for Children Who Stay Behind in South-East Asia, Asian and Pacific Migration Journal, 22 (3), pp. 315-348.

Graham Elspeth, Lucy P Jordan, Brenda S A Yeoh, Theodora Lam, Maruja Asis, and Su-kamdi (2012) Transnational families and the family nexus: perspectives of Indonesian and Filipino children left behind by migrant parent(s), Environ Plan A, 44 (4), [online]. URL: https://www.ncbi.nlm.nih.gov/pmc/articles/PMC3836409/

Graham Elspeth and Brenda SA Yeoh (2013) Introduction: Child Health and Migrant Parents in South-East Asia: Risk and Resilience among Primary Schoolaged Children, Asian and Pacific Migration Journal, 22 (3), pp. 297-314.

Grugel Jean B. and Piper Nicola (2007) Critical Perspectives on Global Governance: Rights and Regulation in Governing Regimes, London, Routledge.

Gulati Leela (1993) In the absence of their men: the impact of male migration on women. Sage, New Delhi.

Hartmann Heid (1981) The family as the locus of gender, class, and political struggle: The example of housework, Signs, 6 (3), pp. 366-394.

Ho Elaine L. E. (2017) The Geo-Social and Global Geographies of Power: Urban Aspirations of "Worlding" African Students in China, Geopolitics, 22 (1), pp. 15-33.

Hoang Lan Anh, Theodora Lam, Brenda SA Yeoh and Elspeth Graham (2015) Transnational migration, changing care arrangements and left-behind children's responses in South-East Asia, Children's Geographies, 13 (3), pp. 263-277, [online]. URL: http://dx.doi.org/10.1080/14733285.2015.972653 
Hoang Lan Anh and Brenda SA Yeoh (2011) Breadwinning Wives and "LeftBehind" Husbands: Men and Masculinities in the Vietnamese Transnational Family, Gender \& Society, 25 (6), pp. 717-739.

Hochschild Arlie (2000) Global care chains and emotional surplus value, in A. Giddens and W. Hutton Eds., On the Edge: Living with Global Capitalism, London, Jonathan Cape, pp. 130-146.

Huang Shirlena and Brenda SA Yeoh (2011) Navigating the terrains of transnational education: Children of Chinese "study mothers" in Singapore, GeoForum, 42 (3), pp. 394-403.

Huguet Jerrold W. (2016) APMJ - Chronicling 25 Years of Migration in Asia and the Pacific, Asian and Pacific Migration Journal, 25 (4), pp. 357-378.

ILO (2015) Global Estimates on Migrant Workers, [online]. URL: https://www.ilo. org/global/topics/labour-migration/publications/WCMS_436343/lang--en/index. htm

International Organization for Migration and Scalabrini Migration Center (2013) Country Migration Report: The Philippines 2013, Makati City and Quezon City, IOM and SMC, $291 \mathrm{p}$.

Jampaklay Aree and Patama Vapattanawong (2013) The Subjective Well-being of Children in Transnational and Non-Migrant Households: Evidence from Thailand, Asian and Pacific Migraiton Journal, 22 (3), pp. 377-400.

Jordan Lucy P., Elspeth Graham and Nguyen Duc Vinh (2013) Alcohol Use among Very Early Adolescents in Vietnam: What Difference Does Parental Migration Make?, Asian and Pacific Migration Journal, 22 (3), pp. 401-420.

Kaur Amajit (2004) Wage Labour in Southeast Asia since 1840: Globalisation, the International Division of Labour and Labour Transformations, Basingstoke, Palgrave Macmillan.

Kim Ann H. (2013) Introduction: Outward and Upward Mobilities: The Global Dispersion of Students from Korea, Asian and Pacific Migration Journal, 22 (4), pp. $465-474$.

Kim Hyun Mee, Park Shinhye and Shukhertei Ariun (2017). Returning home: marriage migrants' legal precarity and the experience of divorce, Critical Asian Studies, 49 (1), pp. 38-53.

Kneebone, Susan (2010) The Governance of Labor Migration in Southeast Asia, Global Governance, 16 (3), pp. 383-396.

Koser Kalid (2010) Introduction: International Migration and Global Governance, Global Governance, 16 (3), pp. 301-315.

Kwak Min-Jung (2013) Immigrant Entrepreneurship and the Opportunity Structure of the International Education Industrt in Vancouver and Toronto, Asian and Pacific Migration Journal, 22 (4), pp. 547-571.

Lan Pei-Chia and Yi-Fan Wu (2016) Exceptional Membership and Liminal Space of Identity: Student Migration from Taiwan to China, Exceptional Membership and Liminal Space of Identity: Student Migration from Taiwan to China, International Sociology, $31(6)$, pp. 742-763.

Lee Sohoon and Piper Nicola (2017) Migrant Domestic Workers as "Agents of Development" in Asia: Collective Organising at the Intersection ofTemporality and Transnationality, in European Journal of East Asian Studies, 16 (2), pp. 220-247. 
Lewis Hannah, Dwyer Peter, Hodkinson Stuart and Waite Louise (2014) Precarious Lives: Forced Labour, Exploitation and Asylum, Bristol, The Policy Press.

Lyttleton Chris (2014) Intimate Economies of Development: Mobility, Sexuality and Health in Asia.

Ministry of Home Affairs (2010) Annual Report 2009/10, New Delhi, Government of India.

Mohan Giles and Tan-Mullins May (2009) Chinese Migrants in Africa as new agents of development: An analytical framework?, European Journal of Development Research, 21 (4), pp. 588-605.

Mohanty Chandra Talpade (1984) Under Western Eyes: Feminist Scholarship and Colonial Discourses, boundary 2, 12 (3), pp. 333-358.

Muir Melinda Wallace and Michelle McMurray Don (2014) Women on the move: the self-initiated expatriate in China, Journal of Global Mobility: The Home of Expatriate Management Research, 2 (2), pp. 234-254.

Nagasaka Itaru and Asuncion Fresnoza-Flot (Eds.) (2015) Mobile Childhoods in Filipino Transnational Families: Migrant Children with Similar Roots in Different Routes, Basingstoke, Palgrave MacMillan, 268 p.

Nah Alice M. (2014) Seeking refuge in Kuala Lumpur: Self-help strategies to reduce vulnerability amongst refugees, in Seng Guan Yeoh Ed., The other Kuala Lumpur: Living in the shadows of a globalising Southeast Asian city, London and New York, Routledge, pp. 146-167.

Neil David and Peterie Michele (2018) Grey Networks: The Contradictory Dimensions of Australia's Immigration Detention System, Asia Pacific Viewpoint, 59 (1), pp. 23-45.

Ogawa Reiko, Raymond K.H Chan, Akiko S. Oishi and Lih-Rong Wang (Eds.) (2017) Gender, Care and Migration in East Asia, Palgrave MacMillan, Singapore, $222 \mathrm{p}$.

Ogaya Chiho (2003) Feminisation and empowerment: Organisational activities of Filipino women workers in Hong Kong and Singapore, in Mamoru Tsuda Ed., Filipino Diaspora: Demography, Social Networks, Empowerment and Culture, Quezon City, the Philippines Philippine Social Science Council and UNESCO.

Orozco Amaia Perez (2009) Global perspectives on the social organization of care in times of crisis: Assessing the situation, UN-INSTRAW Working Paper 5.

Park Donghyun, Arief Ramayandi and Kwanho Hhin (n.d. ) Why Did Asian Countries Fare Better during the Global Financial Crisis than during the Asian Financial Crisis?, Peterson Institute for International Economics, pp. 103-139, [online] last checked on 25/09/2018. URL: https://piie.com/publications/chapters_ preview/6741/04iie6741.pdf

Parreñas Rhacel Salazar (2012) The Reproductive Labour of Migrant Workers, Global Networks, 12 (2), pp. 269-275.

Parreñas Rhacel Salazar (2008) Transnational fathering: Gendered conflicts, distant disciplining and emotional gaps, Journal of Ethnic and Migration Studies, 34 (7), pp. 1057-1072.

Parrenas Rhacel Salazar (2005) Children of Global Migration: Transnational Families and Gendered Woes, Stanford, Stanford University Press. 
Parreñas Rhacel Salazar (Ed.) (2001) Servants of Globalization: Women, Migration and Domestic Work, Stanford, Stanford University Press.

Paul Mary Anju (2017) Multinational Maids: Stepwise Migration in a Global Labor Market, Cambridge, UK and others, Cambridge University Press, 410 p.

Pingol Alicia (2001) Remaking Masculinities: Identity, Power and Gender Dynamics in Families with Migrant Wives and Househusbands, Quezon City, UP Center for Women's Studies, $267 \mathrm{p}$.

Pieke Frank N. (2012) Immigrant China, Modern China, 38 (1), pp. 40-77.

Perera Nirasha and Madhubhasini Rahtnayaka (2013) Sri Lanka's Missing Mothers: A Working Paper on the Effects of Mother Migration. Save the Children Sri Lanka, [online]. URL: https://resourcecentre.savethechildren.net/sites/default/ files/documents/missing_mothers1.pdf

Pieterse Jan (2011) Global Rebalancing, Crisis and the East-South Turn, Development and Change, 42 (1), pp. 22-48.

Piper Nicola (2010) All Quiet on the Eastern Front? - Temporary contract migration in Asia revisited from a development perspective, Policy and Society, 90, pp. 1-13.

Piper Nicola and Iredale Robyn (2003) Identification of the Obstacles to the Signing and Ratification of the UN Convention on the Protection of the Rights of All Migrant Workers 1990 - The Asia Pacific Perspective, prepared for UNESCO, APMRN Working Paper No. 14, University of Wollongong.

Piper Nicola and Lee Sohoon (2016) Marriage Migration at the Intersection of Crisis and Development: Migrant Precarity and Social Reproduction, Critical Asian Studies, 48 (4), pp. 473-493.

Piper Nicola and Ramia Gaby (2018) Transnational Social Governance and Migration: Perspectives from the Asia Pacific, Asia-Pacific Review, 59 (1), pp. 1-5.

Piper Nicola and Roces Mina (Eds.) (2003) Wife or Worker? Asians Marriage and Migration, Boulder/Colorado, Rowan \& Littlefield.

Piper Nicola, Rosewarne Stuart and Withers Matt (2017) Migrant Precarity: "Networks of Labour" for a rights-based governance of migration, Development and Change, 48 (5), pp. 1089-1110.

Piper Nicola and Rother Stefan (2014) More than remittances - Resisting the Global Governance of Migration, Journal fuer Entwicklungspolitik/Austrian Journal for Development Studies, 30 (1), pp. 30-45.

Piper Nicola and Rother Stefan (2012) Let's argue about migration: Advancing a "Rights" Discourse via Communicative Opportunities, Third World Quarterly, 33 (9), pp. 1735-1750.

Piper Nicola and Withers Matt (2018) Forced Transnationalism and Labour Migration: a New Paradigm for Understanding Migrant Rights, Identities: Global Studies in Culture and Power, preview online.

Puwar Nirmal (2003) Melodramatic Postures and Constructions, in Nirmal Puwar and Parvati Raghuram Eds., South Asian Women and the Diaspora, Oxford, Berg Publishers.

Quah Sharon Ee Ling (2015) Perspectives on Marital Dissolution: Divorce Biographies in Singapore, London, Springer. 
Raghuram Parvati (2012) Global care, local configurations-challenges to conceptualizations of care, Global Networks, 12 (2), pp. 155-174.

Rouse Roger (1995) Questions of Identity: Personhood and Collectivity in Transnational Migration to the United States, Critique of Anthropology, 15 (4), pp. 351-380.

Save the Children Sri Lanka (2006) Left Behind, Left Out:The Impact on Children and Families on Mothers Migrating for Work Abroad, Summary Report.

Shen Wei (2010) Globalizing Shanghai: International Migration and the Global City, UNU-WIDER Working Paper No. 2010/79.

Shin Hyunjung (2013) Ambivalent Calculations in Toronto: Negotiating the Meaning of Success among Early Study Abroad Students, Asian and Pacific Migration Journal, 22 (4), pp. 527-546.

Skeldon Ronald (2017) International Migration, Internal Migration, Mobility and Urbanization: Towards More Integrated Approaches, United Nations Expert Group Meeting on Sustainable Cities, Human Mobility and International Migration, Population Division, Department of Economicand Social Affairs United Nations Secretariat, New York 7-8 September 2017, [online]. URL: http:// www.un.org/en/development/desa/population/events/pdf/expert/27/papers/Il/ paper-Skeldon-final.pdf

Smith Monica (2010) Erasure of Sexuality and Desire: State Morality and Sri Lankan Migrants in Beirut, Lebanon, The Asia Pacific Journal of Anthropology, $11(3-4)$, pp. 378-393.

Spitzer Denise and Piper Nicola (2014) Retrenched and Returned: Filipino Migrant Workers During Times of Crisis, Sociology, 48 (5), pp. 1007-1023.

Stark Oded and David E. Bloom (1985) The New Economics of Labor Migration, American Economic Review, 75 (2), pp. 173-178.

Sukamdi and Anna Wattie (2013) Tobacco Use and Exposure among Children in Migrant and Non-migrant Households in Java, Indonesia, Asian and Pacific Migration Journal, 22 (3), pp. 447-464.

Tamkeen Center for Legal aid and Rights (2011) The Weakest Link: Migrant Labor in Domestic and QIZ Sectors in Jordan 2010, Amman/Jordan, TCLAR.

Thieme Susan (2006) Social Networks and Migration - Far West Nepalese Labour Migrants in Delhi, Kultur, Gesellschaft, Umwelt Band 7, Muenster, LIT Verlag.

Truong Thanh-Dam (1996) Gender, Migration and Social Reproduction, Asian and Pacific Migration Journal, 5 (1), pp. 27-52.

Tsong Yuying and Liu Yuli (2009). Parachute kids and astronaut families, in N. Tewari and A. N. Alvarez Eds., Asian American psychology: Current perspectives, New York, Routledge/Taylor \& Francis Group, pp. 365-379.

Blerko Lorraine van and Ansell Nicola (2006) Children's experiences of migration: moving in the wake of AIDS in southern Africa, Environment and Planning D: Society and Space, 24, pp. 449-471.

Waters Johanna (2017) Cross-border childhoods: the role of education in directing mobilities across the Hong-Kong-Shenzhen divide, paper presented at the Intenrational Conference "Children of Migration in Asia", November 25, 2017, Rikkyo University, Tokyo. 
Willis Katie and Yeoh Brenda (2000) Gender and Transnational Household Strategies: Singaporean Migration to China, Regional Studies, 34 (3), pp. 253-264.

World Bank (2017) Annual Remittances Data, [online] last checked on 08/08/2018. URL: http://www.worldbank.org/en/topic/migrationremittancesdiasporaissues/ brief/migration-remittances-data

World Bank Group (2017) Migration and Remittances: Recent Developments and Outlook. Special focus: Transit Migration, [online] last checked on 11/09/2018. URL: https://www.knomad.org/sites/default/files/2018-04/Migration\%20and\%20 Development\%20Brief\%2029.pdf

Yeoh Brenda SA (2014) Engendering International Migration: Perspectives from within Asia, in Graziano Battistella et al., Global and Asian Perspectives on Migration, Springer, pp. 139-152.

Yeoh Brenda S.A. and Kavitha Annadhurai (2008) Civil Society Action and the Creation of "Transformative" Spaces for Migrant Domestic Workers in Singapore, Women's Studies, 37 (5), pp. 548-569. 


\section{Maruja M. B. Asis, Nicola Piper and Parvati Raghuram}

\section{From Asia to the World: "Regional" Contributions to Global Migration Research}

Migration from Asia has become an important theatre of regional and international migration and thus the crucible of theoretical developments which have attracted global attention. Yet, these contributions have not received explicit acknowledgement. This paper sets out to address this gap by outlining the crossborder, mostly South South, migration especially along corridors between and across East, Southeast, South and West Asia. Empirically, cross-border intraregional migration in search for work and livelihoods has been a significant feature in Asia for many decades, with male migrants generally responding to the need for workers in the productive sectors and female migrants mostly (but not exclusively) recruited to care work or other reproductive sectors. Over time, this migration has become increasingly multi-directional and complex in terms of categories of migrants, drivers and outcomes. This paper outlines some of this complexity before going on to focus on three themes - labour migration, impact of migration on the family, and governance and politics - to showcase the regional specificities of migration corridors in Asia. In doing so, it points to the implications of the globalisation of Asian specificities for migration thinking.

\section{De I'Asie au Monde : contributions régionales à la recherche globale sur les migrations}

Les migrations en provenance d'Asie sont devenues un important théâtre de migrations régionales et internationales et donc le creuset de développements théoriques qui ont une portée mondiale. Pourtant, ces contributions n'ont pas reçu de reconnaissance explicite. Cet article vise à combler cette lacune en décrivant les migrations transfrontalières, principalement Sud-Sud, en particulier le long des corridors entre et à travers I'Asie de l'Est, du Sud-Est, du Sud et de l'Ouest. Empiriquement, la migration intrarégionale transfrontalière à la recherche de travail et de moyens de subsistance est une caractéristique importante en Asie depuis de nombreuses décennies, les hommes migrants répondant généralement au besoin de travailleurs dans les secteurs productifs et les femmes migrantes recrutées principalement (mais pas exclusivement) pour travailler dans le secteur des soins ou d'autres secteurs reproductifs. Au fil du temps, cette migration est devenue de plus en plus multidirectionnelle et complexe en termes de catégories de migrants, de déterminants et de résultats. Le présent document décrit une partie de cette complexité avant de développer trois thèmes : la migration de main-d'œuvre, l'impact de la migration sur la famille, la gouvernance et politique - pour mettre en évidence les spécificités régionales des corridors migratoires en Asie. Ce faisant, il met en évidence les implications de la mondialisation des spécificités asiatiques pour la réflexion sur les migrations. 


\section{Desde Asia al mundo: aportaciones regionales a la investigación global sobre las migraciones}

La migración procedente de Asia se ha convertido en un importante escenario de migración regional e internacional $y$, por lo tanto, en un crisol de desarrollos teóricos de alcance mundial. Sin embargo, estas contribuciones no han recibido un reconocimiento explícito. El presente documento tiene por objeto colmar esta laguna describiendo la migración transfronteriza, principalmente la Sur-Sur, en particular a lo largo de los corredores entre y a través de Asia oriental, sudoriental, meridional y occidental. Empíricamente, la migración intrarregional transfronteriza en busca de trabajo y medios de subsistencia ha sido una característica importante en Asia durante muchos decenios, en la que los hombres migrantes en general satisfacen la necesidad de trabajadores en sectores productivos y las mujeres migrantes contratadas principalmente (pero no exclusivamente) para trabajar en el sector de la atención u otros sectores reproductivos. Con el tiempo, esta migración se ha vuelto cada vez más multidireccional y compleja en términos de categorías de migrantes, determinantes y resultados. Este documento describe parte de esta complejidad antes de desarrollar tres temas -la migración laboral, el impacto de la migración en la familia, la gobernanza y las políticas- para poner de relieve las especificidades regionales de los corredores migratorios en Asia. Al hacerlo, destaca las implicaciones de la globalización de las especificidades asiáticas para el pensamiento migratorio. 